\title{
IDENTIFICATION OF PARTNERSHIP PATTERNS AND RICE DISTRIBUTION CHANNELS AS THE MAIN COMMODITY IN SIDENRENG RAPPANG DISTRICT
}

\author{
Aksal Mursalat*, Ayu Wulandary, Fitriani R \\ Department of Agribusiness, Faculty of Science and Technology, University of Muhammadiyah Sidenreng \\ Rappang
}

*corresponding author: aksalmuralat@gmail.com

\begin{abstract}
Sidenreng Rappang Regency is one of the rice providers in South Sulawesi Province in supporting food self-sufficiency in Indonesia. However, there are several problems faced by farmers in Sidenreng Rappang Regency, namely farmers have not been able to optimize their production results due to limited information in determining selling prices, while through a partnership pattern it makes it easier for farmers to obtain information about marketing and other problems, namely the length of distribution channels experienced by farmers. causing the selling price of rice to be classified as very low. The purpose of this research is to identify or study the partnership patterns and distribution channels that have been carried out by rice farmers in Sidenreng Rappang Regency. This research was conducted in Sidenreng Rappang Regency which took place in May-August 2020. The method used was observation and interviews involving 10 rice farmer respondents, then the data were analyzed to determine the implementation of the partnership pattern in the form of a descriptive method and to detect the distribution pattern of rice commodities. Based on the results of the research, the partnership pattern in the rice distribution channel in Sidenreng Rappang Regency is included in the category of general trading patterns, namely by marketing unhulled grain products to rice milling companies through intermediary traders. The implementation of the rice distribution channel system begins with farmers - collectors - rice milling companies, then distributed to two business actors, namely large companies and retailers to the final level to consumers.
\end{abstract}

Keywords: Rice, Partnership Patterns, Distribution Channels

http://dx.doi.org/10.21776/ub.agrise.2020.020.4.3

Received 17 September 2020

Accepted 20 October 2020

Available online 30 October 2020

\section{INTRODUCTION}

Rice is one of the most important staple food products in the world, especially in Indonesia, rice is the main staple food for the majority of the population, be it for the upper, middle, and lower classes, this is because $\geq 95 \%$ of Indonesia's population consumes rice. The province that contributes to rice food in Indonesia is South Sulawesi Province. The harvested area for rice in South Sulawesi is 1.14 million hectares, with an estimated total production of 5.74 tons of GKG. If rice production is converted to rice using the 2018 GKG to rice conversion rate, the rice production is equivalent to 3.28 million tons of rice. Of the total production produced from several regions in South Sulawesi, one of them is the Sidenreng Rappang Regency with a total production of 524,214 tons (BPS, 2018).

With the high amount of production each year along with the high amount of demand for rice consumption each year to meet consumption needs, making rice a major and strategic commodity. (Syaifullah, 2013) added that rice is a unique commodity. Rice has a strategic role in 
strengthening food security, economic resilience, and national political security and stability. However, the problems faced by farmers in Sidenreng Rappang Regency are still not able to optimize their production results due to limitations in marketing, therefore through partnerships make it easier for farmers to obtain information about marketing, therefore farmers must choose based on bonds of trust that have an impact and the best benefits for farming. Through a partnership scheme, agribusiness companies often provide credit to small farmers, production facilities, information, and other means to enable farmers to reach all their needs in the production process (Priandika et al., 2015). (Suryana, 2009) adds that the partnership program can benefit farmers because of the positive perception of plasma farmers participating in the partnership program. This illustrates that farmers still need partnership support from other parties to increase their income. Another advantage of the partnership program with farmers is that if unwanted things happen, such as losses, the farmers do not bear it alone (Suharno et al., 2015).

Another problem is the very low selling price of unhulled rice, while the costs incurred by farmers have not been able to cover the production costs which will certainly have an impact on the welfare of farmers and decrease the amount of rice production. This is inversely proportional to the price received by consumers who obtain higher rice prices. The cause of this price difference is the length of the distribution channel. The length and shortness of the distribution chain that a commodity must pass through also has an impact on prices, which are reflected on the consumer side. The longer the distribution chain, the higher the final price of the commodity (Ahmad, 2012). Each of the distribution channel actors will take advantage of considering the packaging technology applied and the high transportation costs from one place to another to distribute the rice. So to overcome this, we need identification or study of the partnership patterns and distribution channels that have been carried out by rice farmers in the Sidenreng Rappang Regency.

\section{RESEARCH METHODS}

This research was conducted in Sidenreng Rappang Regency starting from May to August 2020. This research used primary data and secondary data. The informants in this study were carried out by purposive sampling technique, namely the selection of informants was carried out deliberately with the consideration that people who have been known to have knowledge, experience, and understand the problems about the object under study (Sugiyono, 2015). Informants who are in accordance with the research needs are people who are directly involved in this matter are rice farmers by attracting 10 respondents. The data collection methods used in this study were observation and interviews. Analysis to determine the implementation of the partnership pattern in the form of descriptive and detection methods to determine the distribution channel of rice commodities requires a direct survey of farmers. The survey results will also be useful in knowing the behavior of producers, distributors, and retailers in the production price formation mechanism. Furthermore, distribution channels will be identified to find out whether there are other distribution channels related to the behavior of producers, distributors, and retailers in the formation of production prices and information will be extracted about the basis for pricing in each of these distribution channels.

\section{RESULTS AND DISCUSSION}

One of the efforts to improve distribution channels in farm marketing is by implementing a partnership pattern. According to (Nuryanti, 2005), one solution to reduce the number of marketing actors in the marketing chain is to build a partnership between farmers and marketing institutions facilitated by the government. The partnership pattern is a form of mutually beneficial cooperation between the two parties to achieve common goals.

The partnership pattern that occurs in the rice commodity marketing distribution channel in Sidenreng Rappang Regency is included in the category of general trade partnership patterns, where farmers market their products in the form of unhulled rice with rice milling companies through trusted intermediary traders, then the rice milling company distributes to various areas both in South Sulawesi and outside the South Sulawesi region. From the partnership pattern that has been established so far, farmers get information about the latest prices from the collecting traders. This is in accordance with the results of (Tiwu et al., 2019) research that the rice supply chain process will run if there are good interaction and communication between supply chain actors. However, usually, the position of collector traders is stronger in determining the quality of unhulled rice than the position of farmers so that the selling price of farmers is still low. This is in line with (Su'udi, 2018), who said that the longer the marketing system, the grain trading system still does not provide justice to farmers because it is more profitable for the traders. Hidayat (2019) added that the longer the distribution pattern and the number of institutions involved can actually reduce the benefits received by farmers as producers. 
To See The Partnership Pattern In The Rice Commodity Marketing Distribution Channel In Sidenreng Rappang Regency, It Can Be Described As The Following Scheme:

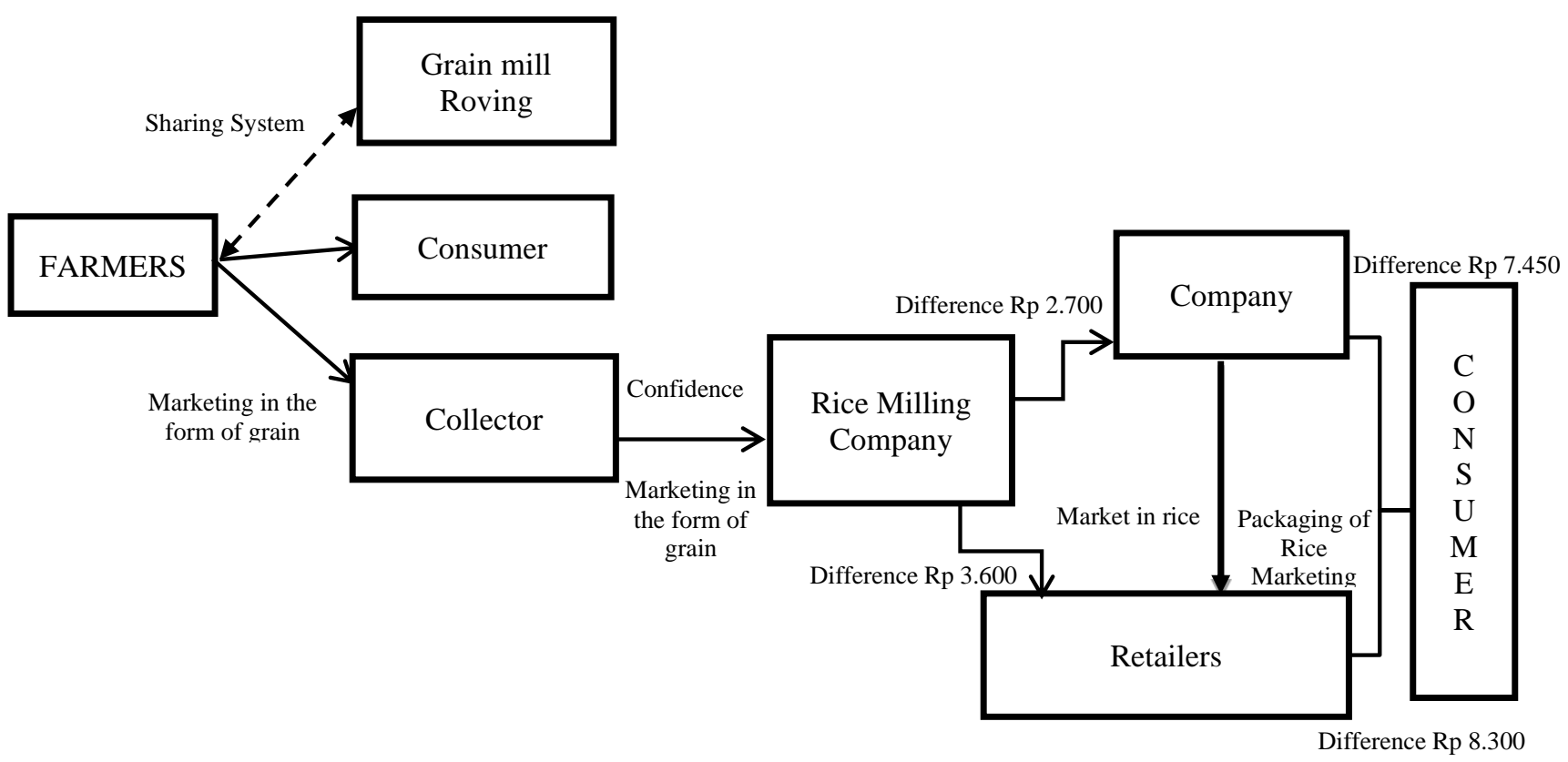

Figure 1. Partnership Pattern in Rice Marketing Distribution Channels

The picture above shows that the implementation of the partnership pattern in the rice commodity marketing distribution channel in Sidenreng Rappang Regency, in this case, the farmers sell their produce in the form of unhulled rice to collectors. Almost all farmers sell their crops in the form of harvested dry unhulled rice (GKP) because of the farmers' need for direct cash. According to (Sobichin, 2012), it is difficult to avoid direct selling of grain by farmers, because, in addition to farmers having urgent needs, in general, they also do not have adequate drying and storage facilities. (Saragih, 2015) add that rice farmers prefer to sell GKP compared to milled dry rice (GKG) because they want cash as soon as possible after harvest. This causes farmers' grain prices to have a very weak bargaining position in the marketing process.

In general, farmers can sell their produce at a higher selling price if they market it in the form of GKG (Milled Dry Grain) with a delay selling system. (Ishak et al., 2018) in his research results stated that farmers who delay selling occupy the top position in the economic structure of rice farmers. The delay in selling is done as a strategy to increase the profit margin from selling GKG. (Sari et al., 2019) adds that if farmers are able to hold their rice production and sell in dry conditions (GKG) or even carry out further processing (such as selling to consumers in the form of rice), surely farmers will get added value from post-harvest or processing carried out.

In marketing the farmer's grain, the price offered by collector traders to farmers is usually around Rp. 5000 / Kg. For the purchasing method, usually, the collector traders will come to the location after receiving a telephone call from the farmer. This is in accordance with the opinion of (Darus, 2018) which states that collecting traders will come directly to the farmer's place in carrying out the grain sales system. (Raspati et al., 2020) emphasizes that farmers do not sell their products directly to wholesalers or consumers but through collectors. Usually, these traders come directly to the location of the producer or even to the houses of the producers to buy the paddy fields so that the producers do not bear the transportation costs, while the payment methods made by the collectors when selling their products are in cash.

Collecting traders have ties of trust to market unhulled rice directly to rice milling companies. In this case, the collector traders get an average purchase price of grain to the company greater than the price offered to farmers with a price difference of Rp. 100 - Rp. 300 depending on the quality provided by the collecting traders. (Saragih et al., 2017) argues that most of the collector traders buy 
farmers' crops in the form of GKP and sell them back to companies in the form of GKP as well and usually the position of the collector traders is stronger in determining the quality of grain compared to the position of farmers. After obtaining unhulled rice from collector traders, the company will process the dried unhulled rice into GKG (Milled Dried Grain), then the processing results in the form of rice are sorted and distributed to retailers and large companies in various regions. According to (Abubakar, 2019), the profit of rice milling companies can increase after processing it into the rice.

Furthermore, large companies and retailers market the rice directly to consumers with a price

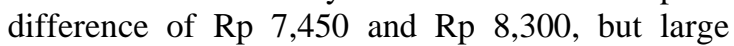
companies market their rice to consumers in the form of packages, it is different with retailers marketing the rice without packaging it first and in the end, the rice arrives. consumer. In addition, large companies also market packaged rice to retailers with a difference of Rp 900 and thereafter to be sold to consumers. So, large companies indirectly sell their packaged rice directly to consumers and retailers. (Partini, 2019) explains that in marketing there are several marketing channels, so there are differences in treatment in the marketing function, marketing costs, marketing margins, marketing profits, and others. (Nurdiana et al., 2020) also argues that in the distribution channel of rice marketing, each marketing component can sell and buy with two business actors, such as wholesalers buying from producers and selling to retailers, if there are no retailers, they can sell to end consumers, while retailers can also buy. from wholesalers and sell them to the final consumer.

Farmers also often market their products to the market for consumption needs, but first, the farmers process the unhulled rice into rice through a mobile grain factory with a production-sharing system, where the mobile grain factory will get $1 \mathrm{~kg}$ of rice for every $10 \mathrm{~kg}$ of unhulled rice. A profit-sharing system is a form of an unwritten agreement that tends to be modest in accordance with custom (Malik et al., 2018).

\section{CONCLUSION}

Based on the results and discussion above, it can be concluded that the partnership pattern in the rice distribution channel in Sidenreng Rappang Regency is included in the category of general trading patterns where farmers market their products in the form of unhulled rice with rice milling companies through trusted intermediary traders, then the milling company. rice distributes to various regions both in South Sulawesi and outside South Sulawesi. The rice distribution channel system begins with farmers traders, collectors - rice milling companies, then distributed to two business actors, namely large companies and retailers to the final level to consumers, causing the selling price of rice to be classified as very low as a result of the length of the distribution channel.

\section{ACKNOWLEDGEMENTS}

The author would like to express his gratitude to the Ministry of Research, Technology, and Higher Education as the provider of research grants as well as to various parties who have helped in preparing the research process until the publication of this manuscript. Special thanks for the careful editing of the manuscript so that it is worthy of publication.

\section{REFERENCES}

Abubakar, R., \& Arif, R. (2019). Keuntungan Pabrik Penggilingan Padi Di Desa Karang Rejo Kecamatan Lalan Kabupaten Musi Banyuasin. Societa: Jurnal Ilmu-Ilmu Agribisnis, 8(1), 65-72.

https://doi.org/https://doi.org/10.32502/jsct.v $8 \mathrm{i} 1.2031$

Ahmad, A. A., \& Priyono, R. (2012). Struktur Pasar Dan Pola Distribusi Beras Sebagai Komoditas Penyumbang Inflasi Utama Di Kabupaten Banyumas. Jurnal Pembangunan Pedesaan, 12(2), 97-105.

Badan Pusat Statistik [BPS]. (2018). Statistik Kabupaten Sidenreng Rappang 2018 : Badan Pusat Statistik Provinsi Sulawesi Selatan.

Darus. (2018). Analisis Pemasaran Padi Sawah Di Kecamatan Rambah Samo Kabupaten Rokan Hulu. Jurnal Agribisnis, 20(1), 1-10. https://doi.org/https://doi.org/10.31849/agr.v2 $0 \mathrm{i} 1.1492$

Hidayat, Y.R. (2019). Sumber Daya Pertanian Berkelanjutan dalam Mendukung Ketahanan dan Keamanan Pangan Indonesia pada Era Revolusi Industri 4.0. Prosiding Seminar Nasional dalam Rangka Dies Natalis UNS Ke 43. Cirebon.

Ishak, A., Firison, J., \& Rokhani. (2018). Keragaman Perilaku Petani Padi Dalam Penjualan Gabah ( Kasus Di Kecamatan Air Manjunto , Kabupaten Mukomuko, Provinsi Bengkulu). Seminar Nasional Program Studi Agribisnis Fakultas Pertanian Universitas Jember, November, 560-568.

Malik, M. K., Wahyuni, S., \& Widodo, J. (2018). Sistem Bagi Hasil Petani Penyakap Di Desa 
Krai Kecamatan Yosowilangun Kabupaten Lumajang. Jurnal Pendidikan Ekonomi: Jurnal Ilmiah Ilmu Pendidikan, Ilmu Ekonomi Dan Ilmu Sosial, 12(1), 26-32. https://doi.org/https://doi.org/10.19184/jpe.v1 2i1.6466

Nurdiana, D., Setiawan, I., \& Isyanto, A. Y. (2020). Jaringan Komunikasi Pemasaran Beras (Studi Kasus pada CV Jembar Rahayu di Desa Sukamantri Kecamatan Ciawi Kabupaten Tasikmalaya). Jurnal Ilmiah Mahasiswa AGROINFO GALUH, 7(1), 166-176. https://doi.org/http://dx.doi.org/10.25157/agr oinfo\%20galuh.v7i1.2573

Nuryanti, S. (2005). Pemberdayan Petani dengan Model Coopertaive Farming. Analisis Kebijakan Pertanian, 3(2), 152-158. https://doi.org/10.21082/akp.v3n2.2005.152159

Partini, \& Pranoto, S. (2019). Sistem Pemasaran Beras Di Kelurahan Kempas Jaya Kecamatan Kempas Kabupaten Indragiri Hilir. Jurnal Agribisnis, $\quad 8(1), \quad 1-8$. https://doi.org/https://doi.org/10.32520/agribi snis.v8i1.811

Priandika, I. M. S., Antara, M., \& Yudhari, I. D. A. S. (2015). Pola Kemitraan Komoditi Padi Sawah Antara P4S Sri Wijaya Dengan Subak Batusangian, Desa Gubug, Kecamatan Tabanan, Kabupaten Tabanan. E-Journal Agribisnis Dan Agrowisata (Journal of Agribusiness and Agritourism), 4(4), 230240.

Raspati, A. B., Yusuf, M. N., \& Hakim, D. L. (2020). Analisis Saluran Pemasaran Komoditas Padi (Studi Kasus di Desa Selasari Kecamatan Parigi Kabupaten Pangandaran). Jurnal Ilmiah Mahasiswa AGROINFO GALUH, 7(1), 97-111. https://doi.org/http://dx.doi.org/10.25157/agr oinfo\%20galuh.v7i1.2563

Saragih, A. E., \& Tinaprilla, N. (2015). Sistem Pemasaran Beras Di Kecamatan Cibeber, Kabupaten Cianjur. Forum Agribisnis, 5(1), $1-24$.

https://doi.org/https://doi.org/10.29244/fagb.5 .1.1-24

Saragih, A. E., Tinaprilla, N., \& Rifin, A. (2017). Rantai Pasok Produk Beras Di Kecamatan Cibeber, Kabupaten Cianjur. Jurnal Manajemen \& Agribisnis, 14(3), 218-229. https://doi.org/https://doi.org/10.17358/jma.1 4.3.218

Sari, E. M., Hasyim, A. I., \& Situmorang, S. (2019). Analisis Efisiensi Pemasaran Gabah Dan Nilai
Tambah Beras Di Kabupaten Pesawaran. Jurnal Ilmu Ilmu Agribisnis, 7(1), 6-13. https://doi.org/http://dx.doi.org/10.23960/jiia. v7i1.6-13

Sobichin, M. (2012). Nilai Rantai Distribusi Komoditas Gabah Dan Beras Di Kabupaten Batang. Economic Development Analysis Journal, 1(2), 1-9. https://doi.org/https://doi.org/10.15294/edaj.v $1 \mathrm{i} 2.478$

Su'udi, D. (2018). Saluran Dan Marjin Pemasaran Gabah Studi Kasus Di Kecamatan Balen Kabupaten Bojonegoro. Jurnal Agribisnis Dan Pertanian Berkelanjutan (ORYZA), 4(1), 13-20.

Sugiyono. (2015). Metode Penelitian Pendidikan (Pendekatan Kuantitatif, Kualitatif dan R\&D). Bandung : CV. Alfabeta.

Suharno, Yuprin, A. ., \& Barbara, B. (2015). Analisis Kinerja Usahatani Perkebunan Kelapa Sawit Rakyat Melalui Pola Kemitraan di Provinsi Kalimantan Tengah. Jurnal Agribisnis Indonesia (Journal of Indonesian Agribusiness), 3(2), 135-144. https://doi.org/https://doi.org/10.29244/jai.20 15.3.2.135-144

Suryana. (2009). Pengembangan Usaha Ternak Sapi Potong Berorientasi Agribisnis Dengan Pola Kemitraan. Jurnal Penelitian Dan Pengembangan Pertanian, 28(1), 29-37. https://doi.org/10.21082/jp3.v28n1.2009.p2937

Syaifullah, Y. (2013). Ketahanan Pangan Dan Pola Distribusi Beras Di Propinsi Jawa Timur. JEJAK: Journal of Economics and Policy, $6(2)$, 103-213 https://doi.org/https://doi.org/10.15294/jejak. v6i2.3881

Tiwu, W. H. La, Sepang, J. L., \& Rate, P. Van. (2019). Analisis Saluran Distribusi Rantai Pasokan Beras Di Bolaang Mongondow (Studi Kasus Di Desa Mopugad Utara Kecamatan Dumoga Utara). Jurnal EMBA: Jurnal Riset Ekonomi, Manajemen, Bisnis Dan Akuntansi, 7(1), 1031-1040. https://doi.org/https://doi.org/10.35794/emba. v7i1.23221 
This page is intentionally left blank 